\title{
Evaluation of Piper betle mediated silver nanoparticle in post-harvest physiology in relation to vase life of cut spike of Gladiolus
}

\author{
Tilak Raj Maity ${ }^{1}$, Aveek Samanta², Babita Saha ${ }^{1}$ and Siraj Datta ${ }^{1 *}$ (B)
}

\begin{abstract}
Background: The purpose of this study is to evaluate the effect of green synthesized silver nanoparticles on postharvest physiology of cut flower in relation to improvement of its vase life as well as keeping quality of the flowers taking gladiolus cut spikes as a model.

Results: The synthesized Piper betle mediated silver nanoparticles (PbSNPs) were characterized by using UVvisible spectroscopy and transmission electron microscopy studies. It was revealed that PbSNPs ranges from 30 to $50 \mathrm{~nm}$ in diameter and spherical in shape. The experiments were conducted to study the effect of PbSNPs on post-harvest physiology, vascular blockage, prolonging vase life, and keeping the quality of cut spike of gladiolus. The treatment consisted of six vase solutions, viz. distilled water (control), 4\% sucrose $\left(T_{1}\right), 4 \%$ sucrose $+100 \mathrm{ppm}$ $5-S S A\left(T_{2}\right), 4 \%$ sucrose +2 ppm PbSNPs $\left(T_{3}\right), 4 \%$ sucrose +4 ppm PbSNPs $\left(T_{4}\right)$, and $4 \%$ sucrose $+6 \mathrm{ppm}$ PbSNPs $\left(T_{5}\right)$. Experimental outcomes depicted that $T_{4}$ vase solution gives the best results in all the aspects statistically compared to its positive control $\left(T_{2}\right)$. The results also show PbSNPs in vase solution might have played a significant role for scavenging the reactive oxygen species by inducing antioxidant enzyme system at the time of senescence, leading to a decrease in lipid peroxidation and increase in the membrane stability.
\end{abstract}

Conclusions: This study revealed that application of $\mathrm{T}_{4}$ vase solution helps to maintain spikes fresh and dry weight, reduce the vascular blockage, improve the antioxidative defense, and stabilize the membrane integrity that leads to delay senescence.

Keywords: Catalase, Gladiolus, Lipid peroxidation, Piper betle leaf extracts, Silver nanoparticles, Superoxide dismutase, Vase life

\section{Background}

Nanotechnology deals with the production and stabilization of various types of nanoparticles. It is a rapidly expanding research field which has tremendous implications on the society, industry, and medicine (Naik et al. 2002; Kemp et al. 2009). Green synthesis of nanoparticles (Singh and Vidyasagar 2014) is an effective method as it is environment-friendly, cost-effective, and easy to scale up for large synthesis and safe to handle. The use of nanoparticles as bactericidal agents represents a new model in the design of antimicrobial therapy against bacteria, viruses, and fungi (Kaviya et al. 2011).

\footnotetext{
*Correspondence: dattasiraj@gmail.com

'Department of Biotechnology, Haldia Institute of Technology, Purba

Medinipur, Haldia, West Bengal 721657, India

Full list of author information is available at the end of the article
}

Silver-ion and silver-based nanoparticles are highly toxic to microorganisms. The mode of action of silver nanoparticles to act as antimicrobial agent is not clearly known. The silver nanoparticle synthesis using plant extracts is preferred as this method is non-toxic, cost-effective, eco-friendly, and easy to scale up in contrast to the chemical procedures which use hazardous material causing adverse effects to this approach (Dubey et al. 2010; Kaushik et al. 2010; Solgi and Taghizadeh 2012; Solgi 2014). Recently, several groups of researchers have synthesized silver nanoparticles using a variety of easily available plants like banana (Bankar et al. 2010), aloe (Chandran et al. 2006), pomegranate and damask rose (Solgi and Taghizadeh 2012), geranium leaves (Shankar et al. 2003), and basil (Ahmad et al. 2010). 
The vase life of a cut flower is the maximum post-harvest day before its senescence. It is important to improve the quality and longevity of cut spikes from harvesting to marketing, and it has a direct commercial impact on floricultural business. That is why it is an interesting area of research to increase the post-harvest days of different cut flowers, i.e. sweet pea (Elhindi 2012), carnations (Baker et al. 1985; Rahman et al. 2012), Gerbera (Van Meeteren 1979; Solgi et al. 2009; Kazemi et al. 2011a), lily (Kazemi et al. 2011b), and roses (Abri 2013). Gladiolus (Gladiolus grandiflorus), one of the economically important garden plants, is cultivated worldwide for cut flower production to use in the valuable floral arrangement.

The metabolic activity and senescence of the cut spike (vase life) are regulated by the different physiological and biochemical processes (Mayak and Halevy 1980; Ahmad and Tahir 2016). The extension of the vase life also depends on the membrane stability and water balance of cut spike. Membrane stability is influenced by reactive oxygen species (ROS). The ROS directly affects the cell membrane integrity (Kazemi et al. 2011a); the free superoxide radicals like $\mathrm{O}_{2}{ }^{-}$and $\mathrm{H}_{2} \mathrm{O}_{2}$ damage the intercellular proteins, lipids, nucleic acid, and pigments leading to senescence. To counter the effect of ROS antioxidant, enzymes like superoxide dismutase (SOD), peroxidase $(\mathrm{PO})$, catalase (CAT) are present; thus, by scavenging ROS, it delayed the senescence (Gill and Tuteja 2010).

Most of the cut flowers are harvested at budding stage to ensure a long post-harvest life and reduce the damages that might be occurred by transpiration and handling. Continual supply of food (carbohydrate) and water are required for the growth of these flower buds during the post-harvest period. Carbohydrates are the important components of storage food as well as a part of structural materials in the floral spike. These carbohydrates also help to increase osmotic pressure, water balance and maintenance of cell's turgor (Marousky 1971). Vase solution is normally used to extend the vase life of the cut flower. The soluble sugar content of cut spikes influence the vase life because stored carbohydrate gives energy for bud opening and floral development (Ho and Nichols 1977). In low sugar content, the flowers senescence rapidly and petals become pale in color. Under these situations, sugar supplements in vase solution can act as stable food source for the floral spike.

Due to the presence of sucrose in the vase solution, which is considered as an unfavorable condition and is associated with many problems, microbial growth occurs (Rodney and Hill 1993). The moisture enters the stem through the cut and exposed sides of the spikes and leads to blockage of the vascular bundles, thus creating an imbalance between water uptake and water loss. They also release secondary metabolites like enzymes or ethylene which are toxic and thus decrease the longevity of the cut spikes. So, addition of an antimicrobial element in sugar solution is essential to prevent the vascular blockage and enhance the vase life. Different chemicals, i.e. silver nitrate, aluminum sulphate, cobalt sulphate, 8-hydroxyquinoline sulphate in different combinations and proportions (Reddy et al. 1997), 5-Sulfo Salicylic Acid (5-SSA) (Ezhilmathi et al. 2007), boric acid, citric acid, and $\alpha$-lipoic acid (Singh 2005), are used in different formulations and combinations to enhance the vase life of cut flowers. Selection of appropriate vase solution or preservative is necessary to extend the vase life and floral quality by studying physiological and biochemical processes of floral senescence.

Here, we report a cost-effective, eco-friendly, and very reproducible method for the large-scale synthesis of silver nanoparticles (SNPs) by reduction process using an ethanolic extract of Piper betle leaf (PbLE). Here, the PbLE act as a reducing and stabilizing agent with an antimicrobial property (Datta et al. 2016). This extract is used for the green synthesis of Piper betle silver nanoparticles (PbSNPs) to prepare commercial vase solution.

The present study was performed to investigate the effect of PbSNPs with respect to the 5-SSA (taken as a positive control) on the post-harvest physiology (effect on antioxidant enzymes, vascular blockage, and vase life of gladiolus cut-spikes) with an objective to find out an appropriate vase solution for enhancing its vase life.

\section{Materials and methods}

\section{Preparation of Piper betle leaf extracts (PbLE)}

Piper betle (ver. Kali Bangla) leaves have obtained from landrace of Paschim Medinipur, West Bengal, India. The material was washed, dried in hot air oven $\left(40{ }^{\circ} \mathrm{C} \pm 1{ }^{\circ} \mathrm{C}\right)$ for $48 \mathrm{~h}$. The dried leaves were grounded into fine powder with mortar and pestle and stored at $-20^{\circ} \mathrm{C}$. The ground powder $(1 \mathrm{~g})$ was Soxhlet extracted using $80 \%$ ethanol for overnight. Final crude extract was concentrated and dried by rotary vacuum evaporator at a temperature less than $50^{\circ} \mathrm{C}$ following concentrated extract which was maintained at $4{ }^{\circ} \mathrm{C}$. Working PbLE stock solution of concentration $10 \mathrm{mg} / \mathrm{ml}$ was prepared by dissolving $100-\mathrm{mg}$ dried crude extract in $500 \mu \mathrm{L}$ of dimethyl sulfoxide (DMSO) and further diluted with distilled water (Maity et al. 2014).

\section{Synthesis of silver nanoparticles from Piper betle leaf extracts (PbLE)}

Silver nitrate $\left(\mathrm{AgNO}_{3}\right)$ was obtained from Sigma Aldrich chemicals. The reduction reaction of pure silver ions $\left(\mathrm{Ag}^{+}\right)$ into silver $\left(\mathrm{Ag}^{0}\right)$ was carried out with PbLE using the method by Kumar et al. (2014). The protocol used involved drop-wise addition of $250 \mu \mathrm{L}$ of PbLE $(1 \mathrm{mg} / \mathrm{ml})$ to $50 \mathrm{ml}$ freshly prepared $1 \mathrm{mM}$ of silver nitrate aqueous solution in a Teflon container. This was stirred continuously at 
different temperature $\left(30{ }^{\circ} \mathrm{C}, 40{ }^{\circ} \mathrm{C}, 50^{\circ} \mathrm{C}, 60^{\circ} \mathrm{C}\right.$, and $70{ }^{\circ} \mathrm{C}$ ) for $4 \mathrm{~h}$ using a magnetic stirrer. This reduction reaction was confirmed by the color change of the solution from colorless to yellowish-brown. When nanoparticles have been formed, the $\mathrm{pH}$ of the aqueous solution was changed using $0.1(\mathrm{~N}) \mathrm{KOH}$ in different $(\mathrm{pH}-6, \mathrm{pH}-7, \mathrm{pH}-8, \mathrm{pH}-9$ and $\mathrm{pH}-10$ ) and incubated for overnight at room temperature.

\section{Characterization of silver nanoparticles}

The UV-vis spectrum of the reduced product was measured in the range of visible region $(300-800 \mathrm{~nm})$ with the help of UV-VIS spectrophotometer (Genesys 10S UV-VIS, Thermo Scientific). The size and morphology of the Piper betle mediated silver nanoparticles were studied by the transmission electron microscopy (TEM) image by using (Philips CM12) at Central Research Facility, Indian Institute of Technology, Kharagpur, India.

\section{Plant material and treatments}

Fresh cut spikes of Gladiolus (Gladiolus grandiflorus) were obtained from a local commercial market (Haldia, West Bengal, India) and brought to the laboratory early in the morning. The spikes were cut uniformly having a length of $65 \mathrm{~cm}$ with six pairs of florets per spike.

The experiments were conducted in completely designed setups by placing the spikes in a $250-\mathrm{ml}$ bottle containing $100 \mathrm{ml}$ of different vase solutions. To prevent the surface evaporation of the vase solution, non-absorbent cotton was used to plug the bottles. The bottles were placed at a room temperature of $25 \pm 2{ }^{\circ} \mathrm{C}$, relative humidity $70 \pm 3 \%$ under continuous illumination (range $400-700 \mathrm{~nm}$ ) system. At every 48 -h intervals, the vase solutions in the bottles were changed and the remaining volume of vase solution was measured. The six vase solutions used were as follows: (1) control, distilled water; (2) $\mathrm{T}_{1}, 4 \%$ sucrose; (3) $\mathrm{T}_{2}, 4 \%$ sucrose $+100 \mathrm{ppm} 5$-SSA; (4) $\mathrm{T}_{3}, 4 \%$ sucrose $+2 \mathrm{ppm}$ PbSNPs; (5) $\mathrm{T}_{4}, 4 \%$ sucrose + 4 ppm PbSNPs; (6) $\mathrm{T}_{5}, 4 \%$ sucrose +6 ppm PbSNPs.

Observations of vase life, fresh weight (FW), height of spike, total solution uptake, flower diameter, relative water content (RWC), number of opened flower, activities of SOD and CAT, lipid peroxidation, total soluble protein, total soluble sugar, chlorophylls and carotenoids content, microbial growth, and vascular blockage were recorded.

All the morphological and biochemical estimations were done in triplicate using flower petal and leaf sample from the post-harvest gladiolus cut spikes at different stages (initial day, 2nd, 5th, 7th, 9th, 12th days of vase life) of flower development.

\section{Vase life}

Vase life of the cut spikes depends on various physical appearances such as slumping down of spike head, flower discoloration, and shedding of petals. Vase life was calculated as the time period during which the fresh weight of the spikes was retained the same to that at the initial day of harvest (Ezhilmathi et al. 2007).

The percentage increase or decrease in fresh weight and height of spikes were recorded at initial day, 2nd, 5th, 7th, 9th, and 12th days of vase life.

\section{Total solution uptake}

The vase solution remaining in the bottles was recorded. Hence, the water uptake was calculated using the following formula.

$$
\begin{aligned}
& \begin{aligned}
N^{\text {th }} \text { day water uptake }(\mathrm{ml}) & =N^{\text {th }} \text { day total volume }(\mathrm{ml}) \\
& -(N-1)^{\text {th }} \text { day total volume }(\mathrm{ml})
\end{aligned} \\
& \text { Water uptake rate }(\mathrm{ml})=\text { amount of water consumed per day }(\mathrm{ml} / \text { day }) \\
& \text { Total water uptake }=\text { water uptake on } N+(N+1) \\
& \qquad \begin{aligned}
\text { th } \\
+(N+2)(N+n)
\end{aligned}
\end{aligned}
$$

\section{Flower diameter}

The mean diameters of the bloomed flowers were recorded on 2nd, 5th, 7th, 9th, and 12th days of vase life. Flower diameter was measured by taking three measurements, which crossed at the center of the opened flowers, and finally, the mean was calculated.

\section{Relative water content}

RWC of the fresh flower petals was recorded by using a 0.5 -g fresh petal sample which was dipped in water for $4 \mathrm{~h}$ to find the turgid weight. Consequently, they were dried in a hot air oven at $80^{\circ} \mathrm{C}$ to achieve a constant weight (Weatherley 1950).

$$
\begin{aligned}
& \text { RWC }=[(\text { Fresh weight }- \text { dry weight }) \\
& \quad /(\text { turgid weight }- \text { dry weight })] \times 100
\end{aligned}
$$

\section{Antioxidant enzymes activity}

The enzyme extract for SOD and CAT was prepared by grinding of a 0.5 -g petal tissue in ice cold extraction buffer (0.1 M potassium phosphate buffer of $\mathrm{pH} 7.6$ containing $0.5 \mathrm{M}$ EDTA) with a pre-chilled mortar and pestle. The homogenate was centrifuged at $4{ }^{\circ} \mathrm{C}$ in refrigerated centrifuge (Remi C-24 plus) for $15 \mathrm{~min}$ at $15,000 \mathrm{rpm}$, and the supernatant was used to determine enzyme activity.

SOD activity was estimated by recording the decrease in absorbance of nitro-blue tetrazolium dye (Dhindsa et al. 1981; Datta Gupta and Datta 2003). Three milliliters of the reaction mixture was prepared which contained $100 \mathrm{mM}$ potassium phosphate buffer ( $\mathrm{pH}-7.6), 100 \mathrm{mM}$ methionine, $1 \mathrm{mM}$ nitro-blue tetrazolium (NBT), 0.5 M EDTA, $0.1 \mathrm{ml}$ enzyme, and distilled water for making up mixture volume. The reaction was started by adding $100 \mu \mathrm{M}$ 
riboflavin and placing the tubes under three $5 \mathrm{~W}$ fluorescent lamps for $15 \mathrm{~min}$. The reaction was stopped on the withdrawal of the light source. The reaction mixture without enzyme was used as a standard. A non-irradiated reaction mixture containing enzyme served as a blank. The tubes which were enzyme less showed the maximum color, and the blank showed no color development. Finally, absorbance was recorded at $560 \mathrm{~nm}$, and one unit of enzyme activity was taken as the quantity of enzyme which reduced the absorbance reading of samples to $50 \%$ in comparison with the reaction mixture lacking enzyme.

CAT activity was obtained by monitoring the decrease in absorbance due to hydrogen peroxide $\left(\mathrm{H}_{2} \mathrm{O}_{2}\right)$ at 240 nm (Aebi 1984; Datta Gupta and Datta 2003). The reaction mixture for measuring the CAT activity consisted of 3- $\mathrm{mL} 50 \mathrm{mM}$ potassium phosphate buffer $(\mathrm{pH}-7), 5 \mu \mathrm{l}$ $\mathrm{H}_{2} \mathrm{O}_{2}$, and $50 \mu \mathrm{l}$ enzyme extract, whereas only 3 -ml 50 $\mathrm{mM}$ potassium phosphate buffer $(\mathrm{pH}-7)$ was served as blank. The reaction began by the addition of $\mathrm{H}_{2} \mathrm{O}_{2}$, and the decrease in the absorbance value was recorded for 30 -s interval of $10 \mathrm{~min}$ at $240 \mathrm{~nm}$. Hence, by taking the standard curve of known concentrations of $\mathrm{H}_{2} \mathrm{O}_{2}$ as a reference, the amount of $\mathrm{H}_{2} \mathrm{O}_{2}$ decomposed was calculated and thus the amount of enzyme activity.

The level of lipid peroxidation depends on the terms of thiobarbituric acid reactive substances (TBARS). Thus, the amount of TBARS was used to determine the lipid peroxidation level (Heath and Packer 1968). The protocol for estimation of lipid peroxidase activity involved homogenization of the petal sample $(0.5 \mathrm{~g})$ in $10 \mathrm{ml} 0.1 \%$ trichloroacetic acid (TCA). The homogenate was centrifuged for $15 \mathrm{~min}$ at $10,000 \mathrm{rpm}$. The supernatant aliquot $(2 \mathrm{ml})$ was added in $4 \mathrm{ml}$ of $0.5 \%$ thiobarbituric acid (TBA) in $20 \%$ TCA. The mixture was then heated at $95^{\circ} \mathrm{C}$ for $30 \mathrm{~min}$ following which it was quickly cooled in an ice bath. The mixture was further centrifuged at $10,000 \mathrm{rpm}$ for 10 min. The absorbance spectrum of supernatant was recorded at $532 \mathrm{~nm}$ and $600 \mathrm{~nm}$. The TBARS content was calculated according to its extinction coefficient $\left[155 \mathrm{mM}^{-1} \mathrm{~cm}^{-1}\right]$. The final result was obtained by subtracting the non-specific absorbance at $600 \mathrm{~nm}$.

\section{Total soluble protein}

The protein sample was prepared by grinding of a $0.5-\mathrm{g}$ petal tissue in ice cold extraction buffer $(0.1 \mathrm{M}$ potassium phosphate buffer of $\mathrm{pH} 7.6$ containing $0.5 \mathrm{M}$ EDTA) with a pre-chilled mortar and pestle. The homogenate was centrifuged at $4{ }^{\circ} \mathrm{C}$ in refrigerated centrifuge (Remi C-24 plus) for $15 \mathrm{~min}$ at $15,000 \mathrm{rpm}$, and the supernatant was used to determine total soluble protein using the Bradford Assay method (Bradford 1976). The absorbance of blue color was read at $595 \mathrm{~nm}$ using UV-VIS spectrophotometer. The amount of protein was quantified by using a standard curve of known concentration.

\section{Total soluble sugar}

The total soluble sugar contents were carried out by hydrolyzing into simple sugars using dilute hydrochloric acid (Sadasivam and Manickam 1996). In the presence of hot acidic medium, glucose is dehydrated to hydroxymethyl furfural. This compound forms with anthrone, a green color product. A $0.5 \mathrm{-g}$ petal sample was hydrolyzed by keeping in a boiling water bath for $3 \mathrm{~h}$ with $5 \mathrm{ml}$ of $2.5 \mathrm{~N}$ $\mathrm{HCl}$. After cooling to room temperature, aqueous sample was neutralized with solid sodium carbonate until the effervescence ceases. The homogenize was centrifuged at $15,000 \mathrm{rpm}$ for $15 \mathrm{~min}$ after making the volume up to $10 \mathrm{ml}$ with distilled water. Five hundred-microliter supernatant was mixed gently with $4 \mathrm{ml}$ of anthrone reagent $(2 \mathrm{mg} / \mathrm{ml})$ and heated for $8 \mathrm{~min}$ in a boiling water bath. The mixture was cooled rapidly and read the green to dark green color at $630 \mathrm{~nm}$. The amount of total soluble sugars present in the sample was calculated using a standard curve of known concentration.

\section{Chlorophyll and carotenoid}

Chlorophyll was extracted with $80 \%$ acetone, and the absorption at $663 \mathrm{~nm}, 645 \mathrm{~nm}$, and $470 \mathrm{~nm}$ was read in a spectrophotometer after being centrifuged twice at 5000 rpm for $5 \mathrm{~min}$ at room temperature. The amount of chlorophyll present in the supernatant was calculated using the following equations (Arnon 1949),

$$
\begin{aligned}
& \text { Total chlorophyll a }\left(\mathrm{mgg}^{-1} \mathrm{FW}\right) \\
& =\left[12.7\left(A_{663}\right)-2.69\left(A_{645}\right)\right] \times\left(\mathrm{V} / W^{*} 1000\right) \\
& \text { Total chlorophyll b }\left(\mathrm{mgg}^{-1} \mathrm{FW}\right) \\
& =\left[22.9\left(A_{645}\right)-4.68\left(A_{663}\right)\right] \times\left(\mathrm{V} / \mathrm{W}^{*} 1000\right) \\
& \text { Total chlorophyll }\left(\mathrm{mg} \mathrm{g}^{-1} \mathrm{FW}\right) \\
& =\left[20.2\left(A_{645}\right)+8.02\left(A_{663}\right)\right] \times\left(\mathrm{V} / \mathrm{W}^{*} 1000\right) \\
& \text { Total carotenoid }\left(\mathrm{mg} \mathrm{g}^{-1} \mathrm{FW}\right) \\
& =\left[1000 \times A_{470}-3.27(\mathrm{chl} \mathrm{a})-104(\mathrm{chl} \mathrm{b})\right] \\
& \quad \div 229\left(V / W^{*} 1000\right)
\end{aligned}
$$

(where $A=$ absorbance at specific wavelength; $V=$ Final volume of chlorophyll extract in $80 \%$ acetone; $W=$ Fresh weight of tissue extracted; chl = Chlorophyll).

\section{Microbial growth}

The evaluation of microbes was studied to determine the effectiveness of PbSNPs in controlling the microbial growth in the vase solution of the cut flowers gladiolus. Ten-microliter vase solutions from each of the bottles were analyzed after 10 times dilution to check the presence of microbes after the 6th day of vase life by placing 
it on nutrient agar (Himedia) media. The bacterial colony was observed and counted after overnight incubation at $37^{\circ} \mathrm{C}$.

\section{Vascular blockage}

Vascular blockage was determined by microscopic observation of the transverse section of xylem vessels. The spike ends were cut on the 6th day of vase life and immediately stained with safranin dye and observed under microscope (Olympus).

\section{Statistical analysis}

Standard errors of the means were calculated, and LSD $(P \leq 0.05)$ was performed to check the level of significance of the difference with the help of ANOVA test using Microsoft Excel data analysis tools.

\section{Results}

\section{Phyto-synthesis of PbSNPs and its characterization}

The aqueous solution of silver nitrate from colorless to yellowish brown indicates the synthesis of silver nanoparticles using ethanolic leaf extracts of Piper betel. The formation of PbSNPs is indicated by reduction of silver ion which leads to the color change (Fig. 1c (ii)). Due to excitation of surface plasmon vibration, the color change to yellowish-brown occurs (Solgi and Taghizadeh 2012). The size and shape of nanoparticles was determined by UV-vis spectroscopy. It was found by earlier researchers that the $\mathrm{pH}$ and incubation temperature of the aqueous solution play an important role in the synthesis of different shapes and sizes of silver nanoparticles (Iravani et al. 2014). The stability of silver nanoparticles depends on the $\mathrm{pH}$ of the working solutions. In our present study, the absorbance of PbSNPs was maximum at $\mathrm{pH}-9$ (Fig. 1a). The UV-vis spectra were recorded on the reaction medium for different temperature-dependent PbSNPs. At temperature $60^{\circ} \mathrm{C}$, the absorption of PbSNPs solution was the highest (Fig. 1b). One narrow absorption band was observed at $420 \mathrm{~nm}$ as shown in Fig. 1c. Transmission electron microscopic analysis showed that the particle size of PbSNPs ranges from 30 to $50 \mathrm{~nm}$ in diameter spherical (Fig. 1c (i)) in shape.

\section{Vase life}

The cut flowers are valued for their long vase life (Bhattacharjee and De 2005). The effect of the different concentration of PbSNPs ( $2 \mathrm{ppm}, 4 \mathrm{ppm}$, and $6 \mathrm{ppm}$ ) in vase solution was observed to extend the vase life of gladiolus cut flower. The vase solution containing PbSNPs expressively increased the vase life of cut spikes. In the case of $\mathrm{T}_{4}$-treated spikes, the vase life was 11.75 days $(95.8 \%$ increased) where as in control, it was the 6th day (Fig. 2). But there was no significant difference in the vase life of cut spikes which were treated with $\mathrm{T}_{2}$ (positive control: $4 \%$ sucrose with $100 \mathrm{ppm} 5$-SSA), $\mathrm{T}_{3}$, and $\mathrm{T}_{5}$. So, $\mathrm{T}_{4}$ was the best vase solution to extend the vase life of cut spike gladiolus followed by $\mathrm{T}_{5}, \mathrm{~T}_{3}$, and $\mathrm{T}_{2}$. Ezhilmathi et al. (2007) reported the extended vase life in 5-SAA-treated gladiolus spike was associated with the increased water uptake, lower respiration rate, and improved water balance.

Gladiolus spike is multi-florets, which opens in an acropetal sequence, and the vase solution quality depends upon the percentage of florets open in the vase. The trend in flower opening was increased day by day during the vase life of the cut spikes treated with PbSNPs as indicated by the flower diameter (Fig. 2, inset). The gladiolus spikes with fully opened flowers when treated with $\mathrm{T}_{4}$ showed the maximum flower diameter $(10.62 \mathrm{~cm})$. The control flowers were smallest in diameter $(9.06 \mathrm{~cm})$ compared to flowers of other five vase solutions. The water uptake and sugar translocation is improved in the presence of PbSNPs, which improves cell division and elongation by exercise of turgor pressure, which also helps in floral opening. There was no significant difference in height between all the treated spikes compared to control (Fig. 2).

\section{Fresh weight, water uptake, and relative water content} The fresh weight of cut spikes treated with $T_{4}$ vase solution was greater than the initial fresh weight up to the 9th day of vase life (Fig. 3). Second day onwards, the fresh weight of control spikes was gradually decreased. Water uptake not only increased the fresh weight but also indicated the supply of food and nutrient through the stems for the flower development. The amount of total solution uptake $(31.87 \mathrm{ml})$ was highest by the cut spikes of $\mathrm{T}_{4}$ vase solution (Fig. 3, inset). Flower turgidity depends on the rate of water uptake and water loss. After the fifth day, RWC was highest in $\mathrm{T}_{4}$-treated vase solution, and then, a gradual decrease was observed. Relative water content of the petal showed that the level of turgidity reached the highest level when the water uptake is greater than the transpiration rate. There was a significant reduction in the fresh weight and total solution uptake of control spikes during the vase life due to the decrease in water uptake or increase in water loss.

\section{Vascular blockage vs. antimicrobial activity of PbSNPs}

Microscopic observation (longitudinal section) of xylem vessels of the cut stem, after the 6th day of treatment control and $\mathrm{T}_{1}$ vase solution treated, showed more vascular blockage (Fig. $4 \mathrm{~m}$, inset) than the stems treated with PbSNPs. The antibacterial activity of PbSNPs was established by the decreasing number of bacterial colonies present in the nutrient agar media with increased PbSNPs concentration in the vase solution. The control $(227 \pm 14$ per plate) and $\mathrm{T}_{1}$ vase solution ( $242 \pm 23$ per plate) contained a significantly higher bacterial load compared to the vase solution containing PbSNPs $\left(\mathrm{T}_{4}: 06 \pm 02\right.$ per plate). The total no. of the bacterial colony was gradually 


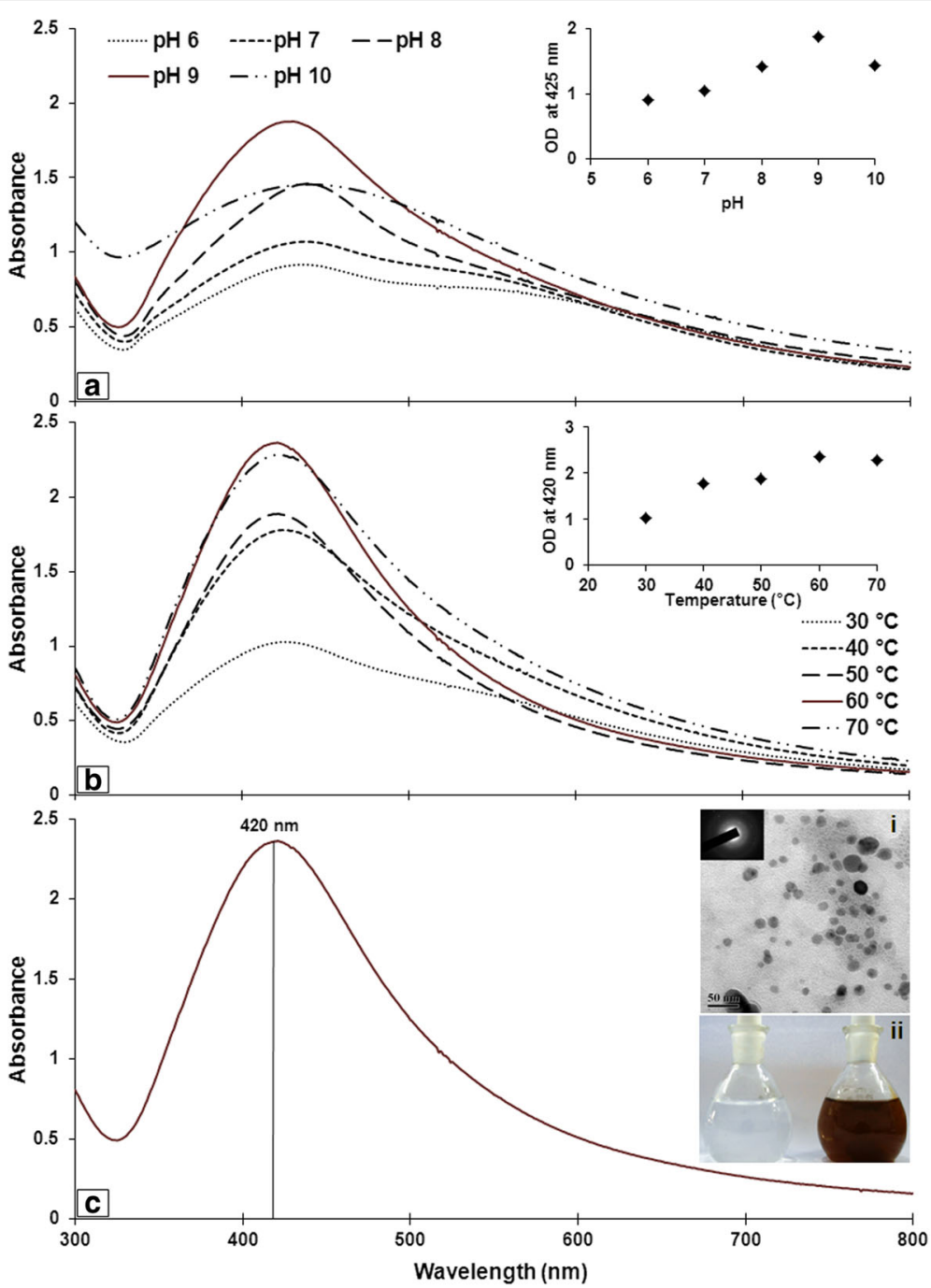

Fig. 1 UV-vis spectra of Piper betle mediated silver nanoparticles recorded after overnight incubation at room temperature: a After being treated at different $\mathrm{pH}(\mathrm{pH}-6, \mathrm{pH}-7, \mathrm{pH}-8, \mathrm{pH}-9$, and $\mathrm{pH}-10)$. b After being treated at different temperatures $\left(30^{\circ} \mathrm{C}, 40^{\circ} \mathrm{C}, 50^{\circ} \mathrm{C}, 60^{\circ} \mathrm{C}\right.$, and $\left.70^{\circ} \mathrm{C}\right)$. c UV-vis spectra of Piper betle mediated silver nanoparticles (incubate: $60^{\circ} \mathrm{C}$; pH 9) showing maximum absorbance at $420 \mathrm{~nm}$. c (i) Transmission electron micrograph (TEM) image of synthesized silver nanoparticles. The SAED pattern of PbSNPs is presented in the inset. $\mathbf{c}$ (ii) Represent color change detected in the reaction mixture containing ethanolic extract of Piper betle leaf and $1 \mathrm{mM}$ silver nitrate solution

decreased with increasing the concentration of PbSNPs in the vase solution (Fig. $4 \mathrm{~g}-\mathrm{l}$ ).

\section{Content of total chlorophyll, soluble sugar, and protein}

When the test sample was treated with sucrose and PbSNPs, it effectively delayed the deterioration of chlorophyll compared to the control as shown in Table 1. The content of chlorophyll a was higher than chlorophyll $b$ during the vase life. There was a significant correlation between degradation of total chlorophyll and carotenoid during the vase life of gladiolus in both the cases of control and treated spikes. The total soluble protein concentration of cut spikes treated with $\mathrm{T}_{4}$ vase solution was recorded as highest at any point of the time throughout the vase life compared to the cut spikes treated with other vase solutions (Table 1). The total soluble sugar concentration was maximum in petals when the cut spike was kept in treated vase solution than control (Table 1).

\section{Antioxidant enzymes activity}

In the present study, SOD activity increased initially until flowers were fully opened and after that activity gradually decreased till senescence. The gladiolus cut spikes treated with $\mathrm{PbSNP}$ vase solution showed enhance activity of SOD in compared to control (Table 2). At day $5, \mathrm{~T}_{4}$ vase solution-treated flowers had thrice the activity of SOD (4.34 units $\mathrm{min}^{-1} \mathrm{mg}^{-1}$ protein) in comparison to control. 


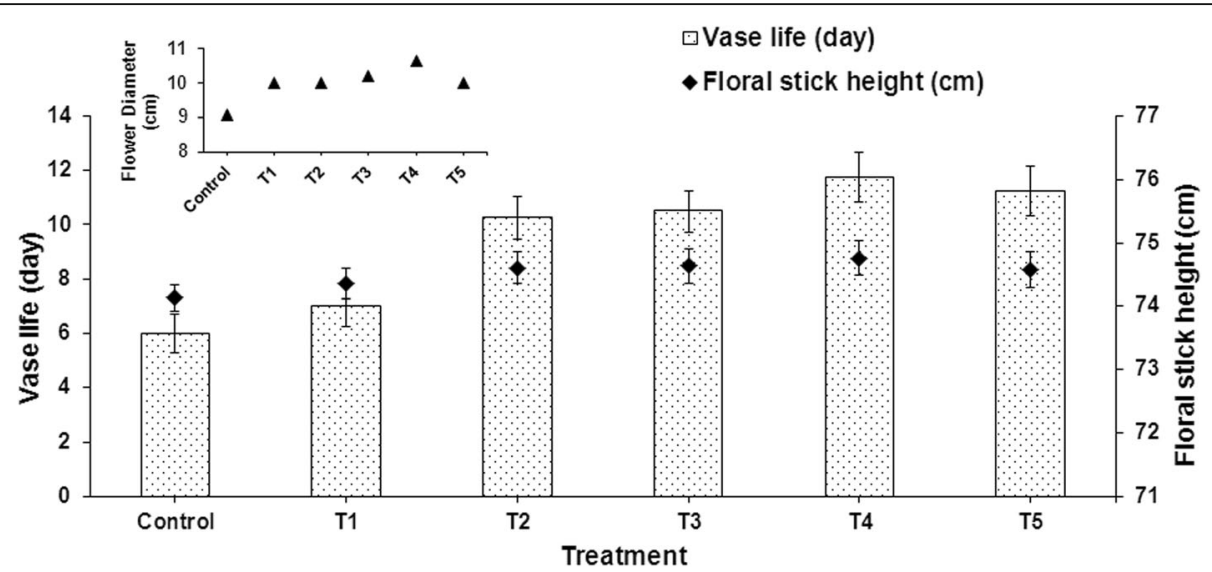

Fig. 2 Effect of different vase solutions (control, $T_{1}, T_{2}, T_{3}, T_{4}$, and $T_{5}$ ) in vase life (day) and floral stick height (cm) of gladiolus cut spikes. Inset represents the average flower diameter of differently treated gladiolus cut spikes during vase life. Vertical bars show \pm SE of mean

Catalase activity decreased continuously from harvest to senescent stage in both control and treated petals of the flowers (Table 2). The spikes treated with PbSNPs vase solution showed slightly higher CAT activity throughout the vase life. Sairam et al. (2011) also observed a steady decrease in CAT activity in cut spike of gladiolus kept in 5-SSA-treated vase solution.

There was a gradual increase in lipid peroxidase activity till senescence in both control and treatment. However, PbSNP vase solution-treated spikes maintained slightly lower lipid peroxidase activity, especially $\mathrm{T}_{4}$ vase solution-treated flowers $(63.06 \mu \mathrm{mol}$ TBARS content $\mathrm{g}^{-1} \mathrm{FW}$ at day 5).

\section{Discussion}

Role of PbSNPs in vase life extension

Vase solution is widely used for the extension of vase life. Thus, effect of PbSNPs in vase solution perhaps exhibited the similar mechanism which is also observed in tuberose spike when Piper betle extract was used in vase solution (Maity et al. 2014) or 8-hydroxyquinoline sulphate (8-HQS) used for snapdragon (Asra 2012). The previous results showed that adding sucrose increased the vase life if the growth of microorganisms was controlled (Ezhilmathi et al. 2007; Moneruzzaman et al. 2010; Saeed et al. 2016). Thus, the presence of PbSNPs in the vase solution plays an important role to expand the vase life by controlling microbial growth. SNPs showed more efficient antimicrobial agent due to their interaction with the bacterial cell membrane (Nabikhan et al. 2010). The antimicrobial effect of SNPs is due to structural changes of the bacterial cell membrane, blockage of DNA replication, the debauchery of proton motive force, and finally cell death (Solgi et al. 2009; Solgi 2014). Antimicrobial activity of plant-mediated synthesized SNPs reported earlier (Kaviya et al. 2011; Maity et al. 2014; Solgi 2014; Yugandhar et al. 2015). Thus, the PbSNPs appeared to be an effective antibacterial agent that significantly reduced the bacterial growth in vase solution as well as vascular blockage in cut spike with its increasing concentration. Li et al. (2017) similarly observed that

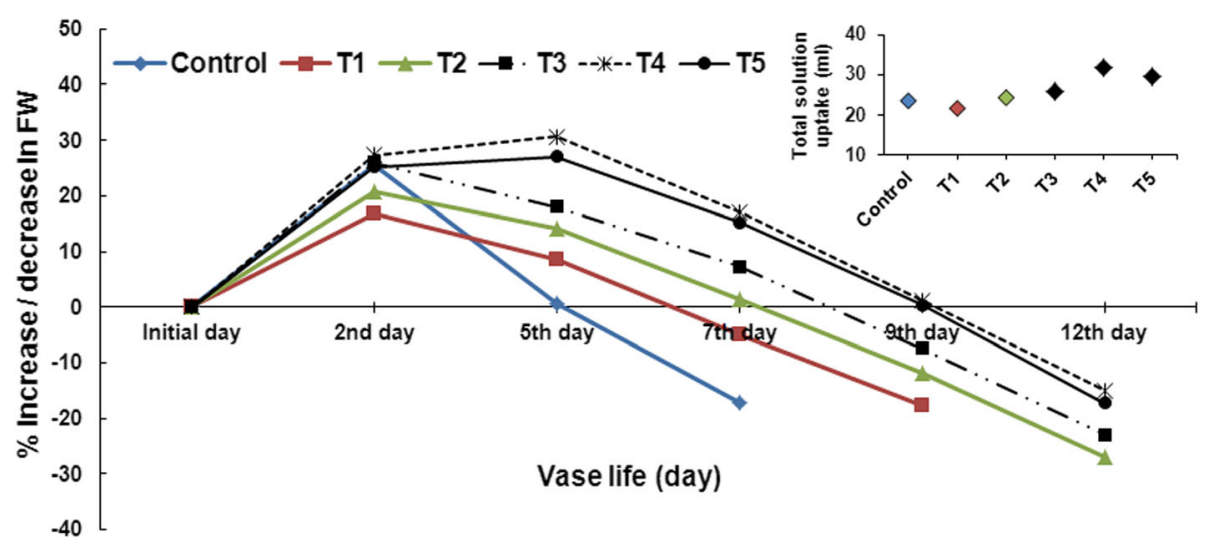

Fig. 3 Effect of different vase solutions (control, $T_{1}, T_{2}, T_{3}, T_{4}$, and $T_{5}$ ) on relative changes in fresh weight of gladiolus cut spikes. Inset represents total solution uptake $(\mathrm{ml})$ during vase life 


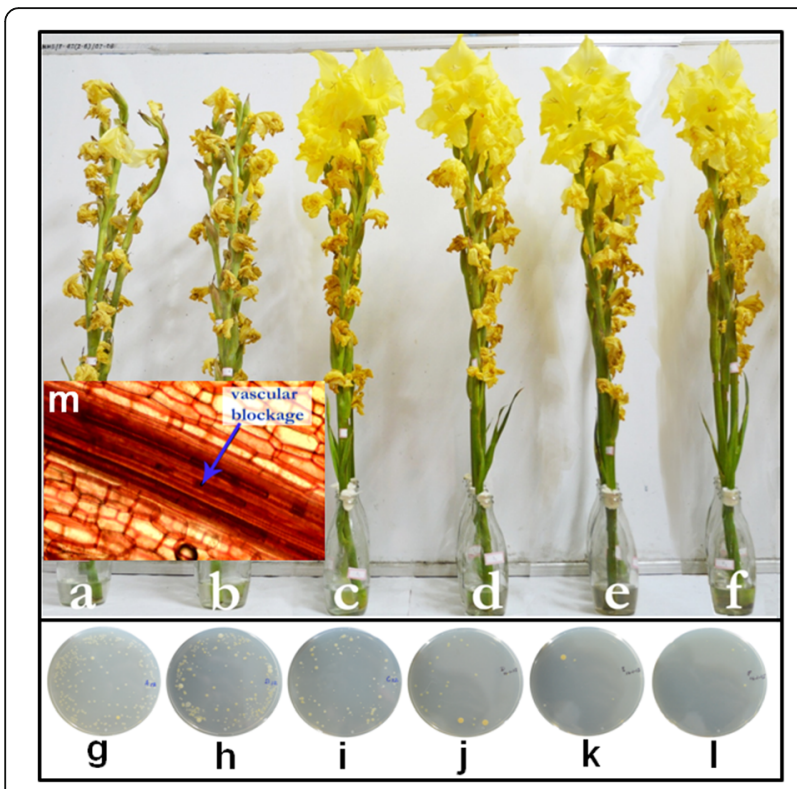

Fig. 4 Gladiolus spikes in different vase solutions at the 9th day of vase life. a Control, b $T_{1}, \mathbf{c} T_{2}, \mathbf{d} T_{3}, \mathbf{e} T_{4}$, and $\mathbf{f} T_{5}$. Microbial colony development at the 7 th day in different vase solutions $\left(10^{-2}\right.$ dilution) were cultured on LB agar plates and observed after overnight incubation at $37^{\circ} \mathrm{C} . \mathbf{g}$ Control, $\mathbf{h} T_{1}, \mathbf{i} T_{2}, \mathbf{j} T_{3}, \mathbf{k} T_{4}$, and $\mathbf{I}$ $T_{5} . \mathbf{m}$ Vascular blockage in vessel observed after the 7 th day by longitudinal sections (LS) of the gladiolus stems treated in $T_{1}$ vase solution

nano-silver (NS) treatment significantly cakes the microbial growth on and in the stem end of Gladiolus "Eerde" spike in association with enhance solution uptake.

There was a relation between fresh weight and solution uptake during vase life. Similar relationships have also been reported by earlier workers (Bieleski and Reid 1992; Borochov et al. 1995; Maity et al. 2014) in daylily, rose, and tuberose. The vase life, the fresh weight of cut spikes, and microbial load resisted in xylem vessel by the use of PbSNPs and helped to maintain the water uptake by floral spike. With the increasing rate of solution uptake, the fresh weight of PbSNPS-treated cut spikes was gradually increased.

The role of total soluble protein and sugar content of the cut spike in relation to vase life

The loss of the protein is related with petal senescence (Kenis et al. 1985). The soluble protein concentration of petals in cut spikes of gladiolus was increased at the initial stages of flower development. With increasing the vase life of gladiolus cut spikes, the soluble protein concentration was decreased rapidly due to little de novo synthesis and protein degradation (Lay-Yee et al. 1992). The total soluble protein concentration of cut spikes treated with $\mathrm{T}_{4}$ vase solution was recorded as the highest at any point of the time throughout the vase life compared to the cut spikes treated with other vase solutions (Table 1).

The total soluble sugar concentration was maximum in petals when the cut spike was kept in treated vase solution than control (Table 1). It was well known that high petal soluble sugar increases the vase life of many cut flowers since they act as a source of primary metabolite (Halevy and Mayak 1981). Sustained level of petal sugar was known to control the hydrolysis of cellular component and the remobilization of the nutrient and retained the flower dry weight as observed in Asiatic lily (Vander JJM et al. 2001).

\section{Role of ROS and antioxidant enzyme activity during vase life of cut spike}

Various studies have already established that vase life of flower was regulated by antioxidant level (Sairam et al. 2011) and involvement of ROS in senescence (Prochazkova et al. 2001; Maity et al. 2014). Studies demonstrated that prolongation of vase life was associated with the scavenging of excess ROS from the cells by antioxidants and ROS scavenging enzymes (Ezhilmathi et al. 2007; Sairam et al. 2011; Datta Gupta and Sahoo 2015). In the present study, SOD activity increased during early days of vase life and declined in the latter phase. It showed the similar pattern worked out by earlier workers studied in rose (Abri 2013), gladiolus (Sairam et al. 2011; Saeed et al. 2014), tuberose (Maity et al. 2014), etc.

Cellular membranes are highly sensitive to ROS, and it is responsible for the progressive decline in membrane stability and probably the consequence of decreasing antioxidant activity. Thus, senescence of flowers was delayed by the use of ROS scavenger, such as sodium benzoate (Baker et al. 1985), n-popylgalate (Mayak et al. 1985), and 5-SSA (Ezhilmathi et al. 2007). Molecular mechanism associated with the increase in SOD and CAT activity in petals of gladiolus spike treated with PbSNPs needed to be explored in the future. Since lipid peroxidation is facilitated by ROS, therefore, either PbSNPs might be decreasing the lipid peroxidation by directly scavenging the ROS, or it might modulate the activity of antioxidant enzymes. A similar result was also found in 5-SSA-treated spike (Ezhilmathi et al. 2007).

\section{Conclusion}

Based on the results of this study, it could be concluded that PbSNPs have the potentiality to improve the vase life of gladiolus cut flower and it may act in two ways to delay the senescence: (i) By acting as a potential antimicrobial agent, it reduced the microbial load. As a result, vascular blockage was also checked and subsequently enhanced the nutrient as well as water uptake in the floral stalk. (ii) By acting as a messenger in 


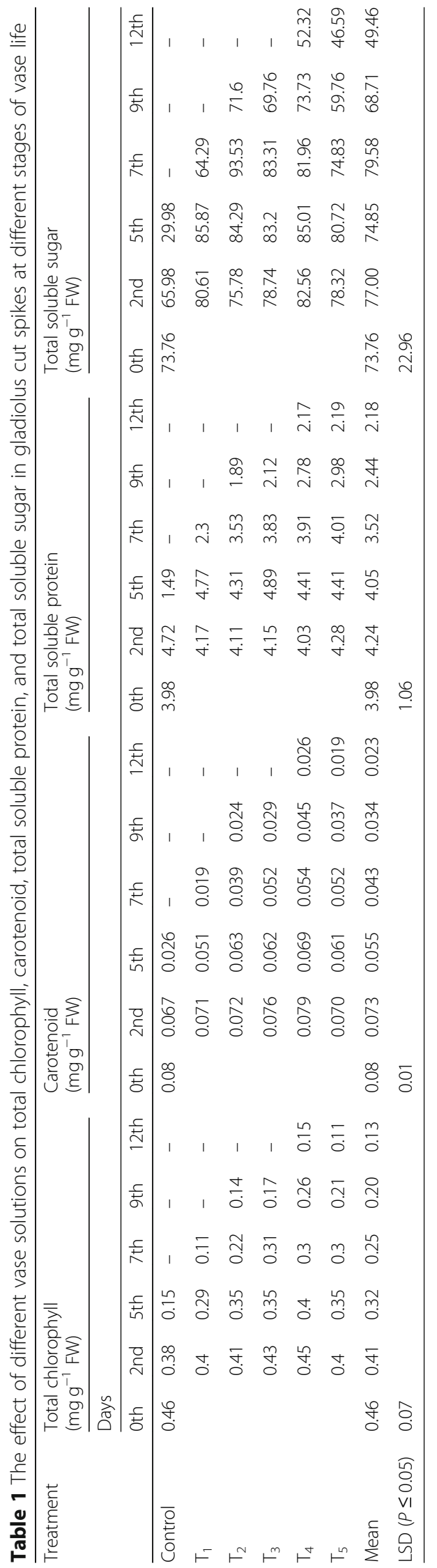


Table 2 The effect of different vase solutions on the activity of superoxide dismutase, catalase, and lipid peroxidation in gladiolus cut spikes at different stages of vase life

\begin{tabular}{|c|c|c|c|c|c|c|c|c|c|c|c|c|c|c|c|c|c|c|}
\hline \multirow[t]{3}{*}{ Treatment } & \multicolumn{6}{|c|}{$\begin{array}{l}\text { Superoxide dismutase activity } \\
\text { (units } \min ^{-1} \mathrm{mg}^{-1} \text { protein) }\end{array}$} & \multicolumn{6}{|c|}{$\begin{array}{l}\text { Catalase activity } \\
\left(\mu \mathrm{mol} \mathrm{min}^{-1} \mathrm{mg}^{-1} \text { protein) }\right.\end{array}$} & \multicolumn{6}{|c|}{$\begin{array}{l}\text { Lipid peroxidation } \\
\left.\text { ( } \mu \mathrm{mol} \text { TBARS content } \mathrm{g}^{-1} \mathrm{FW}\right)\end{array}$} \\
\hline & \multicolumn{18}{|c|}{ Days } \\
\hline & Oth & 2nd & 5 th & 7th & 9th & 12th & Oth & 2nd & 5 th & 7 th & 9th & 12th & Oth & 2nd & 5 th & 7 th & 9th & 12th \\
\hline Control & 2.3 & 2.48 & 1.27 & - & - & - & 12.12 & 10.5 & 6.07 & & & & 40.64 & 69.68 & 100.64 & - & - & - \\
\hline $\mathrm{T}_{1}$ & & 3.31 & 2.36 & 1.02 & - & - & & 11.21 & 8.12 & 5.33 & & & & 61.29 & 87.32 & 117.42 & - & - \\
\hline $\mathrm{T}_{2}$ & & 3.38 & 4.07 & 2.23 & 1.78 & - & & 10.1 & 9.15 & 8.05 & 5.43 & & & 59.68 & 69.68 & 81.22 & 98.84 & - \\
\hline$T_{3}$ & & 3.29 & 4.2 & 2.35 & 1.45 & - & & 11.31 & 10.04 & 8.24 & 6.03 & & & 57.42 & 68.09 & 76.74 & 91.79 & - \\
\hline $\mathrm{T}_{4}$ & & 3.58 & 4.34 & 2.32 & 2.07 & 1.22 & & 10.91 & 10.11 & 9.03 & 7.26 & 5.42 & & 51.56 & 63.06 & 73.76 & 86.8 & 99.34 \\
\hline$T_{5}$ & & 3.48 & 4.14 & 2.47 & 1.81 & 1.17 & & 11.27 & 10.39 & 8.34 & 7.16 & 4.62 & & 55.56 & 65.16 & 78.81 & 89.78 & 106.21 \\
\hline Mean & 2.3 & 3.25 & 3.40 & 2.08 & 1.78 & 1.20 & 12.12 & 10.88 & 8.98 & 7.80 & 6.47 & 5.02 & 40.64 & 59.20 & 75.66 & 85.59 & 91.80 & 102.78 \\
\hline $\operatorname{LSD}(P \leq 0.05)$ & 0.69 & & & & & & 2.19 & & & & & & 40.31 & & & & & \\
\hline
\end{tabular}

the signaling pathway, it may lead to upregulation of SOD, CAT, and lipid peroxidase which scavenge more ROS to delay the senescence.

\section{Abbreviations}

5-SSA: 5-Sulfo salicylic acid; 8-HQS: 8-Hydroxyquinoline sulphate; CAT: Catalase; FW: Fresh weight; PbLE: Piper betle leaf extract; PbSNPs: Piper betle silver nanoparticles; PO: Peroxidase; ROS: Reactive oxygen species; RWC: Relative water content; SNPs: Silver nanoparticles; SOD: Superoxide dismutase; TBARS: Thiobarbituric acid reactive substances; TCA: Trichloroacetic acid

\section{Acknowledgements}

The authors are thankful to the Department of Biotechnology, Haldia Institute of Technology, for providing necessary facilities to carry out the experiments of this work. TEM was done at Indian Institute of Technology, Kharagpur. Authors also acknowledge the effort of Poulomi Saha, Jui Banik, Shatarupa Dey, Ruma Biswas, Priyadharshini Sarkar for generating the primary data of this study during their B.Tech/ M.Tech project.

\section{Funding}

Not applicable.

\section{Availability of data and materials}

All data generated or analyzed during this study are included in this published article.

\section{Authors' contributions}

TRM and AS performed the experiments, analyzed the data, and wrote the manuscript. BS and SD designed the work and corrected the manuscript. The entire authors read and approved the final manuscript

\section{Ethics approval and consent to participate}

Not applicable.

\section{Consent for publication}

Not applicable.

\section{Competing interests}

The authors declare that they have no competing interests.

\section{Publisher's Note}

Springer Nature remains neutral with regard to jurisdictional claims in published maps and institutional affiliations.

\section{Author details}

'Department of Biotechnology, Haldia Institute of Technology, Purba Medinipur, Haldia, West Bengal 721657, India. ' ${ }^{2}$ Department of Botany, Prabhat Kumar College, Purba Medinipur, Contai, West Bengal 721401, India.

Received: 25 October 2018 Accepted: 9 January 2019

Published online: 22 January 2019

\section{References}

Abri F (2013) Effect of ascorbic acid on vase life and petal senescence in cut rose flowers (Rosa hybrida) cv. 'Royal Class'. Am Eurasian J Agric Environ Sci 13(1):38-43 Aebi H (1984) Catalase in vitro. Meth Enzymol 105:121-126

Ahmad N, Sharma S, Alama MK, Singh VN, Shamsi SF, Mehta BR, Fatmae A (2010) Rapid synthesis of silver nanoparticles using dried medicinal plant of basil. Colloids Surf B: Biointerfaces 81:81-86

Ahmad SS, Tahir I (2016) How and why of flower senescence: understanding from models to ornamentals. Indian J Plant Physiol 21:446-456

Arnon DI (1949) Copper enzymes in isolated chloroplasts. Polyphenoloxidase in Beta vulgaris. Plant Physiol 24:1-15

Asra AWA (2012) Effects of some preservative solutions on vase life and keeping quality of snapdragon (Antirrhinum majus L.) cut flowers. J Saudi Society of Agric Sci 11(1):29-35

Baker JE, Wang CY, Terlizzi DE (1985) Delay of senescence in carnations by pyrazon, phenidone analogues and Tiron. Hort Sci 20:121-122

Bankar A, Joshi B, Kumar AR, Zinjarde S (2010) Banana peel extract mediated novel route for the synthesis of silver nanoparticles. Colloids Surf $A$ Physicochem Eng Asp 368:8-63

Bhattacharjee S, De LC (2005) Post-harvest technology of flowers and ornamental plants. Aavishkar Publishers, Jaipur, pp 11-19

Bieleski RL, Reid MS (1992) Physiological changes accompanying senescence in the ephemeral daylily flower. Plant Physiol 98:1042-1049

Borochov A, Spiegelstein H, Porat R, Field T (1995) Membrane lipids involved in the regulation of flower senescence. Acta Hort 405:240-245

Bradford M (1976) A rapid and sensitive method for the quantification of microgram quantities of protein utilizing the principle of protein-dye binding. Anal Biochem 72:248-254

Chandran SP, Chaudhary M, Pasricha R, Ahmad A, Sastry M (2006) Synthesis of gold nanotriangles and silver nanoparticles using Aloe vera plant extract. Biotechnol Prog 22:577-583

Datta Gupta S, Datta S (2003) Antioxidant enzyme activities during in vitro morphogenesis of gladiolus and the effect of application of antioxidants on plant regeneration. Biol Plant 47:179-183

Datta Gupta S, Sahoo TK (2015) Light emitting diode (LED)-induced alteration of oxidative events during in vitro shoot organogenesis of Curculigo orchioides Gaertn. Acta Physiol Plant 37:233. https://doi.org/10.1007/s11738-015-1990-9

Datta S, Jana D, Maity TR, Samanta A, Banerjee R (2016) Piper betle leaf extract affects the quorum sensing and hence virulence of Pseudomonas aeruginosa PAO1. 3 Biotech 6:18. https://doi.org/10.1007/s13205-015-0348-8 
Dhindsa RS, Plumb-Dhindsa D, Thorpe TA (1981) Leaf senescence: correlated with increased levels of membrane permeability and lipid peroxidation, and decreased levels of superoxide dismutase and catalase. J Exp Bot 32:93-101

Dubey SP, Lahtinen M, Sillanpaa E (2010) Green synthesis and characterizations of silver and gold nanoparticles using leaf extract of Rosa rugosa. Colloids Surf A Physicochem Eng Asp 364:34-41

Elhindi KM (2012) Evaluation of several holding solutions for prolonging vase-life and keeping quality of cut sweet pea flowers (Lathyrus odoratus L.). Saudi J Biol Sci 19:195-202

Ezhilmathi K, Singh VP, Arora A, Sairam RK (2007) Effect of 5-sulfosalicylic acid on antioxidant activity in relation to vase life of gladiolus cut flowers. Plant Growth Regul 51:99-108

Gill SS, Tuteja N (2010) Reactive oxygen species and antioxidant machinery in abiotic stress tolerance in crop plants. Plant Physiol Biochem 48:909-930

Halevy AH, Mayak S (1981) Senescence and postharvest physiology of cut flowers. Part 2, Hortic Rev 3:59-141

Heath RL, Packer L (1968) Photo-peroxidation in isolated chloroplast I. Kinetics and stoichiometry of fatty acid peroxidation. Arch Biochem Biophys 125:189-198

Ho LC, Nichols R (1977) Translocation of 14C-sucrose in relation to changes in carbohydrate content in rose corollas cut at different stages of development. Ann Bot 41:227-242

Iravani S, Korbekandi H, Mirmohammadi SV, Zolfaghari B (2014) Synthesis of silver nanoparticles: chemical, physical and biological methods. Res Pharm Sci 9(6): 385-406

Kaushik N, Thakkar MS, Snehit S, Mhatre MS, Rasesh Y, Parikh MS (2010) Biologica synthesis of metallic nanoparticles. Nanomed Nanotechnol Biol Med 6:257-262

Kaviya S, Santhanalakshmi J, Viswanathan B, Muthumary J, Srinivasan K (2011) Biosynthesis of silver nanoparticles using citrus sinensis peel extract and its antibacterial activity. Spectrochim Acta A 79:594-598

Kazemi M, Zamani S, Aran M (2011a) Effect of some chemical treatments on keeping quality and vase-life gerbera cut flowers. Am J Plant Physiol 6:99-105

Kazemi M, Zamani S, Aran M (2011b) Interaction between glutamin and different chemicals on extending the vase life of cut flowers of 'Prato' lily. Am J Plant Physiol 6:120-125

Kemp MM, Kumar A, Mousa S, Park TJ, Ajayan P, Kubotera N, Mousa S, Linhardt RJ (2009) Synthesis of gold and silver nanoparticles stabilized with glycosaminoglycans having distinctive biological activities. Biomacromolecules 10(3):589-595. https://doi.org/10.1021/bm801266t

Kenis JD, Silvente ST, Trippi VS (1985) Nitrogen metabolism and senescence associated changes during growth of carnation flowers (Dianthus caryophyllus). Physiol Plant 65:455-459

Kumar S, Singh M, Halder D, Mitra A (2014) Mechanistic study of antibacterial activity of biologically synthesized silver nanocolloids. Colloids Surf A Physicochem Eng Asp 449:82-86

Lay-Yee M, Stead AD, Reid MS (1992) Flower senescence in daylily (Haemerocallis). Physiol Plant 86:308-314

Li H, Li H, Liu J, Luo Z, Joyce D, He S (2017) Nano-silver treatments reduced bacterial colonization and biofilm formation at the stem-ends of cut gladiolus 'Eerde'spikes. Postharvest Biol Technol 123:102-111

Maity TR, Samanta A, Jana D, Saha B, Datta S (2014) Effect of Piper betle leaf extract on post-harvest physiology and vascular blockage in relation to vase life and keeping quality of cut spike of tuberose (Polianthes tuberosa L. CV. Single). Ind J Plant Physiol 19(3):250-256

Marousky FJ (1971) Inhibition of vascular blockage and increased moisture retention in cut roses induced by $\mathrm{pH}, 8$-hydroxyquinoline citrate and sucrose. J Amer Soc Hort Sci 96:38-41

Mayak S, Borochov A, Tirosh T (1985) Transient water stress in carnation flowers: effect of amino-oxyacetic acid. J Expt Bot 36:800-806

Mayak S, Halevy AH (1980) Flower senescence. In: Thimann K (ed) Senescence in plants. CRC Press, Boca Raton, pp 131-156

Moneruzzaman KM, Hossain ABMS, Amru NB, Saifudin M, Imdadul H, Wirakarnain $S$ (2010) Effect of sucrose and kinetin on the quality and vase life of Bougainvillea glabra var. Elizabeth Angus bracts at different temperatures. Aust J Crop Sci 4(7):474-479

Nabikhan A, Kandasamy K, Raj A, Alikunhi NM (2010) Synthesis of antimicrobial silver nanoparticles by callus and leaf extracts from saltmarsh plant Sesuvium portulacastrum L. Colloids Surf B: Biointerfaces 79:488-493

Naik RR, Stringer SJ, Agarwal G, Jones SE, Stone MO (2002) Biomimetic synthesis and patterning of silver nanoparticles. Nat Mater 1(3):169-172
Prochazkova D, Sairam RK, Srivastava GC, Singh DV (2001) Oxidative stress and antioxidant activity as the basis of senescence in maize leaves. Plant Sci 161: 765-771

Rahman MM, Ahmad SH, Lgu KS (2012) Psidium guajava and Piper betle leaf extracts prolong vase life of cut carnation (Dianthus caryophyllus) flowers. Scientific World J. https://doi.org/10.1100/2012/102805

Reddy BS, Singh K, Gangadharappa PM (1997) Influence of 8-hydroxy quinoline sulphate and sucrose on post-harvest physiology of tuberose cv. Double. Karnataka J Agric Sci 10:1049-1054

Rodney BJ, Hill M (1993) The effect of germicides on the longevity of cut flowers. J Am Soc Hortic Sci 118(3):350-354

Sadasivam S, Manickam A (1996) Biochemical methods, 2nd edn. New age international (p) Ltd. Publisher, New Delhi, pp 179-186

Saeed T, Hassan I, Abbasi NA, Jilani G (2014) Effect of gibberellic acid on the vase life and oxidative activities in senescing cut gladiolus flowers. Plant Growth Regul 72(1):89-95

Saeed T, Hassana I, Abbasia NA, Jilani G (2016) Antioxidative activities and qualitative changes in gladiolus cutflowers in response to salicylic acid application. Sci Hort 210:236-241

Sairam RK, Vasanthan B, Arora A (2011) Calcium regulates gladiolus flower senescence by influencing antioxidative enzymes activity. Acta Physiol Plant 33:1897-1904

Shankar S, Ahmad A, Sastry M (2003) Geranium leaf assisted biosynthesis of silver nanoparticles. Biotechnol Prog 19:1627-1631

Singh SP, Vidyasagar GM (2014) Green synthesis, characterization and antimicrobial activity of silver nanoparticles by using Sterculia foetida $\mathrm{L}$. young leaves aqueous extract. Int J Green Chem Bioprocess 4(1):1-5

Singh VP (2005) Deterioration of membrane during flower senescence in Gladiolus and its amelioration with free radical scavenger. J Ornam Hortic 8:8-12

Solgi M (2014) Evaluation of plant-mediated silver nanoparticles synthesis and its application in postharvest physiology of cut flowers. Physiol Mol Biol Plants 20(3):279-285

Solgi M, Kafi M, Taghavi TS, Naderi R (2009) Essential oils and silver nanoparticles (SNP) as novel agents to extend vase life of Gerbera (Gerbera jamesonii cv. 'Dune') flowers. Postharvest Biol Technol 53:155-158

Solgi M, Taghizadeh M (2012) Silver nanoparticles ecofriendly synthesis by two medicinal plants. Int J Nanomater Biostructures 2(4):60-64

Van Meeteren Y (1979) Water relations and keeping quality of cut gerbera flowers VI. Water content, permeability and dry weight of ageing petals. Sci Hort 10:261-269

Vander JJM M-M, Van Overen JC, LHW VP, Van Tuyl JM (2001) Post-harvest flower development in Asiatic hybrid lilies as related to petal carbohydrate status. Postharvest Biol Technol 21:201-211

Weatherley PE (1950) Studies in water relations of cotton plants I. The field measurement of water deficit in leaves. New Phytol 49:81-97

Yugandhar P, Haribabu R, Savithramma N (2015) Synthesis, characterization and antimicrobial properties of green-synthesised silver nanoparticles from stem bark extract of Syzygium alternifolium (Wt.) Walp. 3 Biotech 5(6):1031-1039

\section{Submit your manuscript to a SpringerOpen ${ }^{\circ}$ journal and benefit from:}

- Convenient online submission

- Rigorous peer review

- Open access: articles freely available online

- High visibility within the field

- Retaining the copyright to your article

Submit your next manuscript at $>$ springeropen.com 